九州大学学術情報リポジトリ

Kyushu University Institutional Repository

\title{
On four species of Pontoni inae (Crustacea, Decapoda, Palaemonidae, ) found in Porifera inhabiting the coastal regions of Kyushu, Japan
}

Miyake, Sadayoshi

Zoological Laboratory, Department of Agriculture, Kyushu University

Fujino, Takahiro

Zoological Laboratory, Department of Agriculture, Kyushu University

https://doi.org/10.5109/22761

出版情報：九州大学大学院農学研究院紀要. 14 (2)，pp.275-291，1967-03. Kyushu University バージョン：

権利関係 : 
Journal of the Faculty of Agriculture, Kyushu University, Vol. 14, No. 2 March 30, 1967

On four species of Pontoniinae (Crustacea, Decapoda, Palaemonidae,) found in Porifera inhabiting the coastal regions of Kyushu, Japan ${ }^{1,2)}$

Sadayoshi Miyake and Takahiro Fujino

It is well known that many prawns belonging to the subfamily Pontoniinae inhabit with certain marine invertebrates such as Porifera, Coelenterata, Mollusca, Echinodermata and Tunicata. In the present paper are described four pontoniid prawns including one new species, Periclimenaeus ohshimai, two new records to the fauna of Japan, Anchistioides compressus Paulson and Onycocaris quadratophthalma (Balss), and a known species, Periclimenaeus gorgonidarum (Balss), which are all commensal with Porifera. The specimens were collected in the shallows of Amakusa Islands, west of Kyushu and of Tsuyazaki, Fukuoka Prefecture, north of Kyushu in 1965 to 1966. According to Holthuis (1952), some species belonging to the following genera, Anchistioides, Onycocaris, Periclimenaeus, Periclimenes and Typton of the subfamily Pontoniinae have been recorded to accompany with Porifera, though the species of the Porifera have hardly been known. This time we were fortunately instructed about the species of Porifera by Dr. S. Tanita.

We wish to express our hearty thanks to the gentlemen who offered us the interesting specimens. Our special thanks must be extended to Emeritus Professor Hiroshi Ohshima of the Kyushu University who has provided us with facilities required for the pursuit of this work, and to Dr. Senji Tanita of the Japan Sea Regional Fisheries Research Laboratory for the identification of Porifera.

\section{Periclimenaeus ohshimai sp. nov.}

(Fig. 1, a-g)

Types. Holotype, $\sigma^{\rtimes}$, Zoological Laboratory, Kyushu University (ZLKU) No. 3431, Takamatsu, Amakusa Islands, Kyushu, Aug. 16, 1932, H.

1) Contributions from the Zoological Laboratory, Faculty of Agriculture, Kyushu University, No. 358.

2) Contributions from the Amakusa Marine Biological Laboratory, Kyushu University, No. 199. 
Ohshima leg. Paratype, 1 ovig. 우, ZLKU No. 3432, Takamatsu, Amakusa Islands, Kyushu, Aug. 16, 1932, H. Ohshima leg.

Description of holotype. The body is slender and rather compressed.

The rostrum is straightly directed forwards; the tip is pointed and reaches just to the end of the second segment of the antennular peduncle; the upper border is slightly convex with six teeth situated equidistantly, the first of which is placed over the posterior margin of the orbit; only one small tooth is placed between the tip and the distal tooth of the upper border.

The carapace is gencrally swollen and smooth, except for the small supraorbital spine placed somewhat behind the posterior margin of the orbit and a strong antennal spine just situated on the top of the orbital angle; the anterolateral margin is straight (Fig. 1, a).

The eye is well developed, reaching almost to the end of the first segment of the antennular peduncle; the cornea is as broad as the eyestalk.

The first segment of the antennular peduncle is broad; the stylocerite is rather broad and short and ends in a sharp point, not reaching so far anteriorly as the middle of the first segment; the anterolateral angle of the first segment forms a strong sharp point reaching to the end of the second; the second and third segments are slightly produced forwards, each forming a small lobe at the anterolateral corner; the outer flagellum is bifurcated into two rami at the third fused joint, the shorter of which is half times as long as the fused joints; there are many setae on the ventral sides of the fused joints and shorter ramus.

The antennal scale is rather broad, becoming narrower anteriorly; the outer margin is slightly concave, and ends in a strong anterolateral tooth which extends slightly beyond the end of the lamella, and this tooth reaches to the end of the third segment of the antennular peduncle; the inner margin is convex at the middle (Fig. 1, b).

The ultimate segment of the third maxilliped is slightly longer than the penultimate; the antepenultimate segment, the base of which is considerably broad, is compressed and about three times as long as the penultimate; the exopod extends slightly beyond the end of the antepenultimate segment.

The first pereiopod is rather slender; the movable finger is short and about half the palm in length and directed outwards; the chela bears tufts of setae anteriorly; the palm is elongated and four times as long as broad; and the cutting edges are entire, without any tooth; the carpus and merus are slender and equal in length, being one and a half the length of the chela (Fig. 1, c).

The second pereiopods both are lacking in our specimen. 
The last three perciopods are almost similar in shape but different in size, decreasing in order from the third to fourth, and fifth; they are peculiar in the structures of the dactyli; the apical part of each dactylus is articulated with the rest part of the dactylus, and measures less than one-fourth times the length of the rest; the apical part is

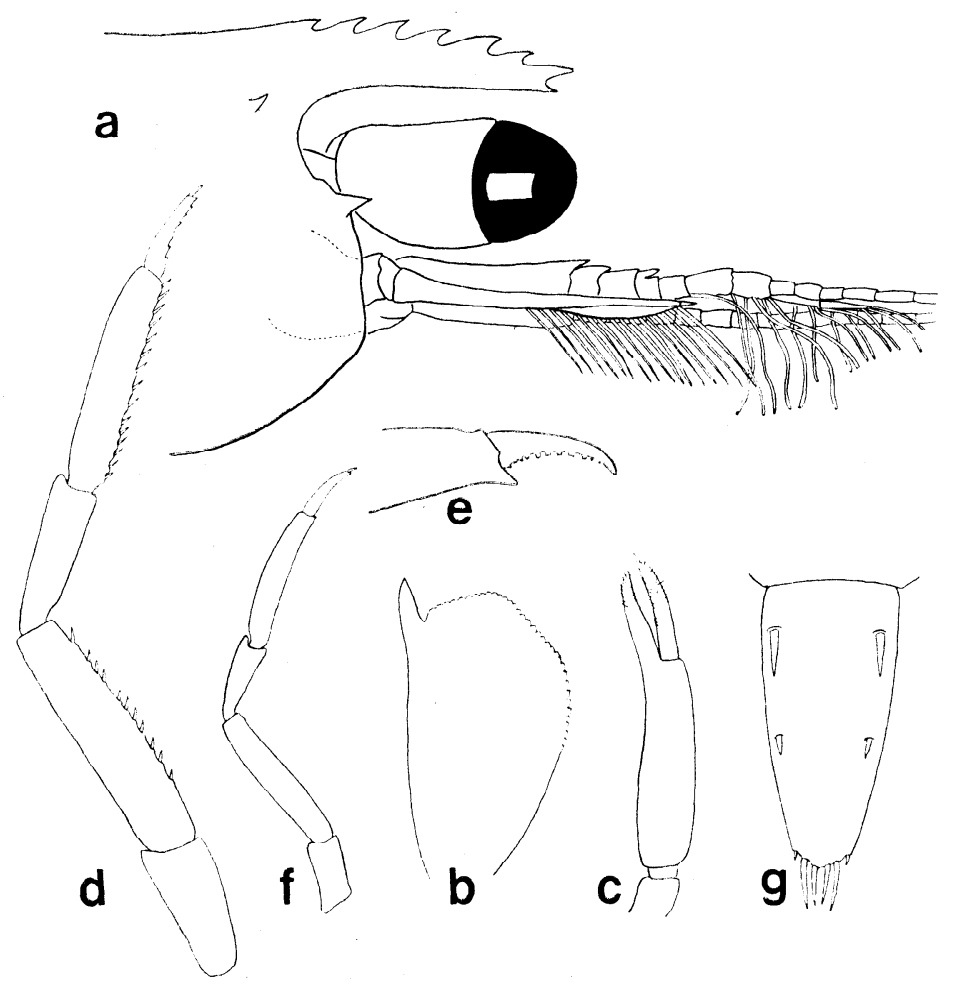

Fig. 1. Periclimenaeus ohshimai sp. nov., holotype, male.

a, Anterior part of body, $\times 33$; b, antennal scale, $\times 33$; c, chela of first pereiopod, $\times 33$; d, third pereiopod, $\times 16$; e, apical part of third pereiopod, $\times 44 ; \mathrm{f}$, fifth pereiopod, $\times 16$; $\mathrm{g}$, telson, $\times 16$.

provided at the posterior border with eight to ten small denticles which are truncated or bluntly pointed; the apex is obtusely pointed too, slightly curving posteriorly; the dactylus except for the apical part bears eight to ten small teeth and a distal strong protuberance slightly directed ventrally at the lower border, gradually decreasing its breadth towards the articulation. The propodus of the third pereiopod is less than two and a half the length of the dactylus, and is provided with many spines at the lower margin; the merus is longer than 
the propodus and four times as long as broad, being convex posteriorly, and is armed with the spines which are fewer than those of the propodus; the fifth pereiopod is short without any conspicuous tooth (Fig. 1, d-f).

The abdomen is smooth; the ventral margin of each pleuron of the first three abdominal segments is broadly round and that of the fourth is narrowly pointed, and in the fifth it has a blunt point; the pleuron of the fifth segment is as long as the sixth; the posterolateral margin of the pleuron of the sixth segment turns into an obtuse triangular flange. The appendix masculina is shorter than the appendix interna and has a long seta provided with fine plumes.

The tclson is twice as long as broad at the base; it is provided with two pairs of the dorsal spines, the proximal is situated near the base, while the distal is placed near the middle of the telson; there are three pairs of terminal spines at the end of the telson, the outer is the shortest, and the rest are subequal in length though the middle is somewhat stronger than the inner (Fig. 1, g). The uropod is about as long as the telson; the outer margin of the exopod is not serrated and ends in two blunt triangular processes.

Paratype. The only one ovigerous female specimen is considerably dameged in the body but has both the second pereiopods. The second pereiopods are strong and different in size and shape. In the larger cheliped the movable finger has a truncated tooth on the cutting edge which fits into the shallow hollow on the cutting edge of the immovable one; the distal part of the chela is slightly inturned; the dorsal side of the movable finger is round; the palm is swollen, slightly compressed, and twice as long as broad, the surface of which is rugose with fine hairs. In the smaller cheliped, the movable finger has a thin cutting edge which extends from the proximal one-fifth point to the end of the movable finger, and also fits into the shallow groove carved on the cutting edge of the immovable finger; the carpus is triangular-shaped, and is two-thirds times the length of the merus and as long as the ischium.

The first pereiopod is slenderer than that of the holotype, and the carpus is slightly shorter than twice the length of the chela. This regard in the morphological character is the only conspicuous difference from the holotype specimen.

\begin{tabular}{lcc}
\multicolumn{1}{l}{ Measurements $(\mathrm{mm})}$. & \\
& Holotype $\left(\mathrm{o}^{-}\right)$ & Paratype (ovig. + ) \\
Length of carapace & 1.9 & 3.4 \\
Breadth of carapace & 1.7 & 3.1 \\
Length of rostrum & 0.9 & 1.2 \\
Length of scaphocerite & 1.0 & 1.3 \\
Length of telson & 1.3 & 2.0
\end{tabular}


Remarks. The species is closely related to Periclimenaeus arthrodactylus Holthuis (1952), but differs from his description and figures in the following regards. In $\boldsymbol{P}$. arthrodactylus, the rostrum is slender and direceddownwards, reaching beyond the eye, and is provided with five teeth on the upper border, of which the distal is situated far behind the tip of the rostrum, but none on the lower. In the present species, however, the rostrum is straightly directed forwards and reaches just to the end of the eye, being armed with six teeth situated equidistantly on the upper border and one tooth near the tip on the lower border. The posterior margin of the apical part except for the rest of each dactylus of the last three pereiopods has four to six small denticles in $\boldsymbol{P}$. arthrodactylus, whereas in the present species eight to ten teeth are placed at the same place. The rest part of each dactylus of the last three pereiopods except for the apical part, is very slender, and one and a half the length of the propodus and the posterior margin is entire in $P$. arthrodactylus, while in the present species the dactylus is not so slender as in Holthuis' description, measuring at least two and a half the length of the propodus, and is armed with several teeth on the posterior margin. The tip of the dactylus of the fifth pereiopod is truncated, not forming a sharp or blunt claw in his figure, instead of that of the present species being pointed. There are four pairs of terminal spines at the distal end of the telson in $P$. arthrodactylus, but in the present species there are three. This species, as already mentioned, is remarkable for its singular structure of each dactylus of the last three pereiopods.

The present species was commensal with the sponge, Callyspongia elegans (Thiele), which commonly lives in the shallow waters southwards from the middle of the Main Island (Honshu) in Japan to the southwards, Malay Archipelago, Indian Ocean and Australia.

\section{Anchistioides compressus Paulson, 1875}

(Figs. 2 and 3 , a-d, pl. 3)

Anchistioides compressus Paulson, 1875, p. 115, pl. 19, fig. 5 (original description) [1961, p. 121, pl. 19, figs. 5-5n] ; Nobili, 1906, p. 54 (description); Kemp, 1925, p. 339 (description); Gordon, 1939, p. 334, fig. 22 (key); Holthuis, 1952, p. 18 (list).

Material examined. Uze, Tomioka, Amakusa Islands, Kyushu, gill net for spiny lobster fishing, 1 ㅇ, ZLKU No. 3406, April 8, 1965, A, Taki leg.

Uzc, Tomioka, Amakusa Islands, Kyushu, dredge, 1 ovig. 우, ZLKU No. 3407, July 21, 1966, Y. Miya leg.

Uze, Tomioka, Amakusa Islands, Kyushu, gill net for spiny lobster 
fishing, ㅇ, 1 ZLKU No. 3426, Sept. 8, 1966, A. Taki leg.

Description. The body is smooth except for the longitudinal ridges running on the carapace and abdomen (Fig. 2).

The rostrum is straight and somewhat deep in lateral view, extening slightly beyond the end of the antennal scale; the upper border is rather convex and armed with ten to twelve teeth which lie equidistantly, and the first is situated at the proximal one-fifth point of the rostrum; there are eight teeth on the lower border with a shallow concavity, and they are shorter and less erected than those of the upper.

The carapace is somewhat swollen and as long as the rostrum; it is curved downwards towards the eye at the anterior part of the supraorbital tubercle; the anterolateral margin of the carapace is round; two obscure ridges run backwards, one from the supraorbital tubercle and the other from just behind the eye, and the region between these ridges is concave.

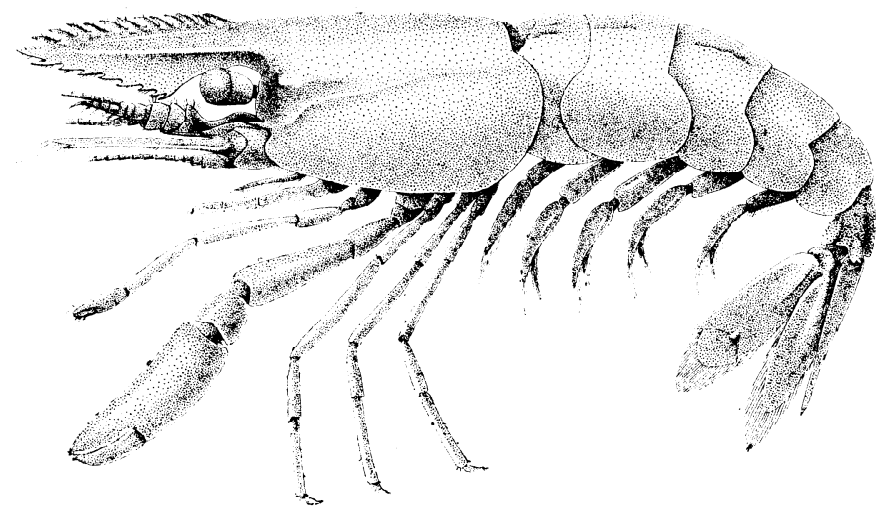

Fig. 2. Anchistioides compressus Paulson, $\ 6.0$.

The eye is rather small, reaching to the third tooth of the upper border of the rostrum; the eyestalk is slightly shorter than the cornea.

The first segment of the antennular peduncle is somewhat broad, and at the anterolateral margin there is a sharp spinc which reaches to the end of the second segment; the stylocerite is rather broad and directed outwards, the tip of which is sharply pointed, extending to the middle of the first segment; the anterolateral margin of the second segment is round, not forming a spine nor lobe; the third segment reaches near the middle of the rostrum; the outer antennular flagellum is bifurcated into two rami at the third fused segment, the shorter of which consists of four joints (Fig. 3, a). 
The antennal scale is somewhat elongated and as long as the rostrum, becoming narrower towards the tip; the anterolateral tooth is large and directed outwards; the end of the lamella forms an acute triangle reaching beyond the anterolateral tooth (Fig. 3, b).

The third maxilliped is provided with an epipod but not an exopod; the ultimate segment is as long as the penultimate and two-fifths times the length of the antepenultimate.

The first pereiopod reaches as far as the end of the antennal scale; the movable finger is not so broad as the immovable one and as long as the palm; the cutting edge of the immovable finger is slightly convex, instead of being concave in that of the movable one, and both of the edges are not provided with setae.
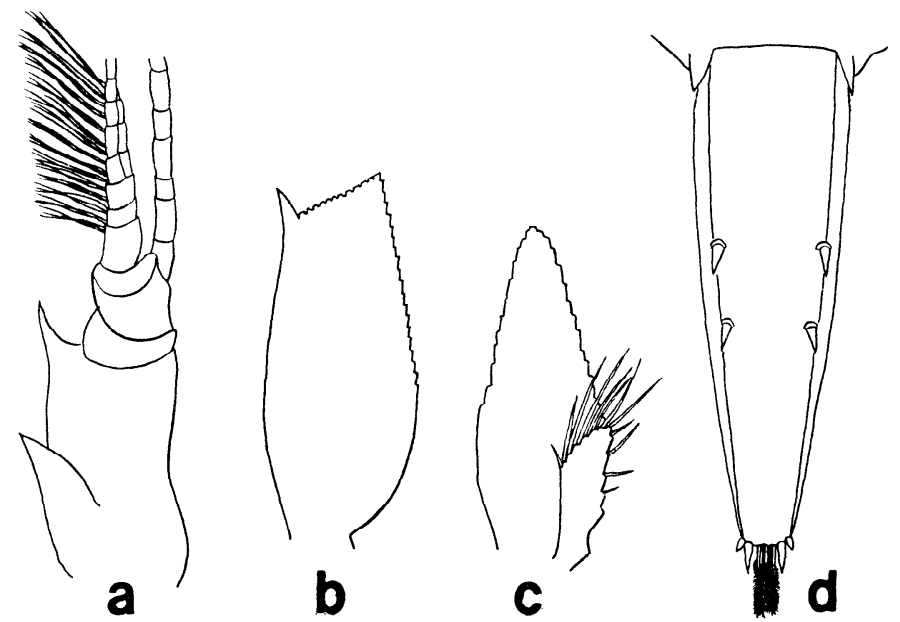

Fig. 3. Anchistioides compressus Paulson, a, antennular peduncle ; b, antennal scale; c, first pleopod; d, telson.

The second pereiopods, which is slightly inturned at the tip and less than half the length of the palm, are rather small and symmetrical, extending beyond the antennal scale by the length of the movable finger, the chela is flat dorsally but somewhat swollen ventrally; the fingers are deeply hollowed inwards.

The third pereiopod is slender and extends slightly beyond the end of the antennular peduncle; the dactylus is curved ventrally, the tip of which is a sharp claw armed with a very small protuberance on the posterior margin closely near the tip of the dactylus; a pair of the spinules is placed at the distal end of the posterior border of the propodus, and one spine is situated in the distal third point of the same border, 
but both fourth and fifth pereiopods lack this spine; the propodus of the third pereiopod is longer than the carpus; the fourth and fifth pereio pods resemble the third in shape.

The endopod of the first pleopod lacks the appendix interna (Fig. 3, c).

The anterior margin of the pleuron of the first abdominal segment is slightly concave; the ventral margins of all the segments are round; there are one or two longitudinal ridges on the terga of the first three segments, and these ridges are obscure in the ovigerous female.

The telson is slender; the base is about three times as broad as the distal end; the breadth of the telson is nearly equal at the base and at the middle, but becomes narrower from the middle towards the distal end; it has a deep longitudinal groove on the dorsal side and two ridges are formed near the lateral margins of the telson; there are two pairs of dorsal spinules on the ridges, dividing the length of the telson into the intervals with proportions of seven to three to eight from the base; the end of the telson is furnished with two pairs of the terminal spines, the inner of which is about two and a half times as long as the outer; two pairs of setae are placed between the inner pair (Fig. 3, d). The uropod is as long as the telson.

Colour. The body of the non-ovigerous female is transparent in life, but turns into white entirely in alcohol. In the ovigerous one, it is also transparent with some red pigments which are not disappeared even in alcohol, being scattered at the base of the telson and uropod. The eggs in life are light green and turn themselves into bitter orange in alcohol.

$\begin{array}{lccc}\quad \text { Measurements (mm). } & & & \\ \quad \text { ZLKU Cat. No. } & 3406 \text { (우) } & 3407 \text { (ovig. 우) } & 3426 \text { (우) } \\ \text { Length of carapace } & 4.5 & 6.0 & 3.0 \\ \text { Breadth of carapace } & 3.1 & 5.6 & 3.7 \\ \text { Length of rostrum } & 4.2 & 6.0 & 3.3 \\ \text { Length of scaphocerite } & 3.3 & 4.3 & 2.5 \\ \text { Length of telson } & 3.0 & 4.0 & 2.3 \\ \text { Length of movable finger } & 1.6 & 2.0 & 1.0 \\ \text { Length of palm } & 1.7 & 2.8 & 1.5\end{array}$

Distribution. This species may be new to the fauna of Japan. The records in literature are: Red Sea (Paluson, 1961 ${ }^{1)}$; Nobili, 1906), Andaman Islands (Kemp, 1925).

Remarks. The present specimens agree well with Paulson's ${ }^{1)}$ description, in which the supraorbital tubercle is not found on the carapace, but it is now regarded as one of the characters of the genus Anchisti-

1) We referred to the English translation of the original Russian publication for 1875. 
oides. Perhaps he might have overlooked it because of its being indistinct. Moreover, Holthuis (1952) reports that the appendix interna developed on the endopod of the first pleopod in both sexes is one of the distinctive characters of this genus, but it is absent in all our female specimens as mentioned above.

It has been known that the species belonging to this genus are either free-living or commensal with sponges. The specimens here dealt were all commensal with the sponges of the two species, Caminus sp. and Haliclona oculata (Linnaeus), and the latter may be distributed throughout the world.

One of the ovigerous female, thus observed, was found lied on the bottom of the osculum of the sponge, Haliclona oculata (Linnaeus), as seen in the plate 3 .

Onycocaris quadratophthalma (Balss, 1921)

(Figs. 4 and 5 , a-e)

Pontonia quadratophthalma Balss, 1921, p. 15 (original description) ; Kemp, 1922, p. 261 (key); Edmondson, 1925, p. 7 (description); Edmondson, 1946 , p. 250 , fig. 150 c (description).

Onycocaris quadratophthalma: Holthuis, 1952, p. 147 (key), p. 150 (description); Holthuis, 1955, p. 63 (Key), fig. 36 (after Balss).

Material examined. Takamatsu, Amakusa Islands, Kyushu, $1 \delta^{\jmath}, 1$ ovig. ㅇ, ZLKU No. 3438, Aug. 16, 1932, H. Ohshima leg.

Tomioka, Amakusa Islands, Kyushu, gill net, $2 \precsim ð, 4$ ovig. 우 우, ZLKU No. 3440, Sept. 6, 1966, A. Taki leg. ${ }^{1)}$

Shiroiwazaki, Tomioka, Amakusa Islands, Kyushu, $78 \precsim ð$ ๙., 88 우 우, ZLKU No. 3508, April 3, 1930, H. Ohshima leg.

Description. The body is smooth and rather compressed (Fig. 4).

The rostrum is very short and triangular-shaped in dorsal view, not being provided with any tooth; the upper margin is slightly carinated and curved downwards, and the distal end is slightly directed upwards, reaching about to the midway between the cornea and the eyestalk.

The carapace is round and swollen, becoming slender anteriorly; it is as long as broad; the posterolateral margin is strongly curved downwards, turning to the ventral margin; the orbital margin is not deeply concave, and the orbital angle is triangular-shaped with a tip bluntly pointed.

The eye is short and rather broad; the cornea is shorter and narrower than the eyestalk, and is placed at the anterolateral side of the

1) Among these specimens Cat. Nos. 3444 (ovig. 우) and 3445 (ovig. 우) are preserved in the Amakusa Marine Biological Station. 
eyestalk.

The first segment of the antennular peduncle is elongated; the stylocerite is bluntly pointed, forming a small lobe directed forwards, and reaches about to the middle of the first segment; the second segment is shorter than the third, together thcy are half the length of the first; the outer flagellum is bifurcated into two rami at the third or fourth

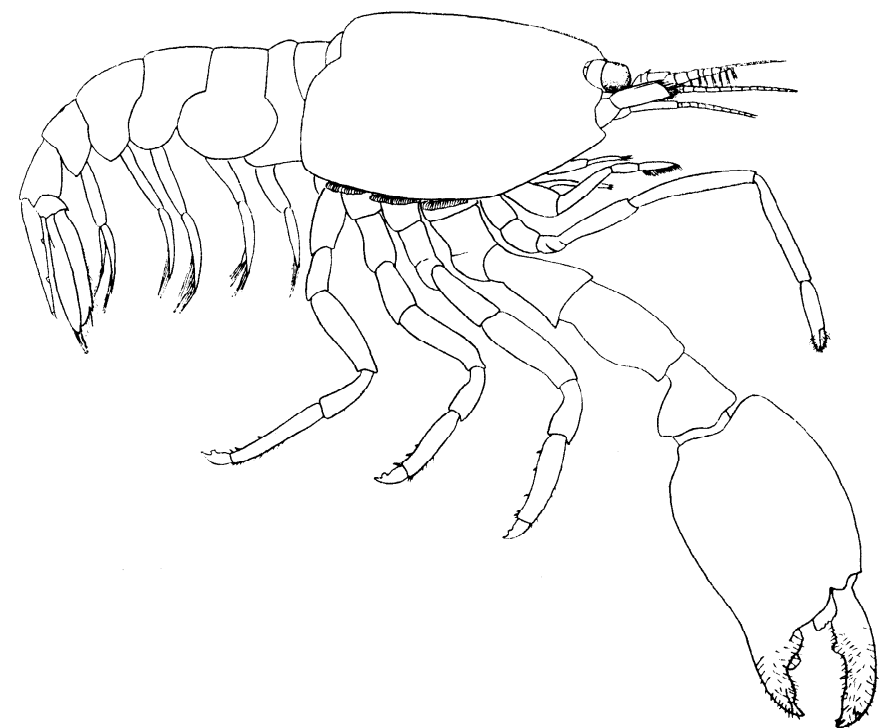

Fig. 4. Onycocaris quadratophthalma (Balss), $\times 8.9$

fused joint, the longer of which consists of six joints while the shorter is two (Fig. 5, a).

The antennal scale is considerably small and oval-shaped, and is more than twice as long as broad, extending to the end of the third segment of the antennular peduncle; the outer margin terminates in a small tooth which does not reach to the end of the lamella (Fig. 5, b).

The ultimate and penultimate segments of the third maxilliped are subequal in length; the antepenultimate is long and broad; the exopod slightly extends beyond the end of the antepenultimate.

The first pereiopod is slender; the palm is more than twice as long: as the movable finger; the carpus is slender and becomes broader distally, and is subequal to the merus in length.

The second pereiopods are large and strong, both being similar in shape but slightly different in size; the movable finger is curved ventrally, and is narrower and slightly longer than the immovable one; on the cutting edge of the movable finger there are two or three small 
teeth in the proximal half and a thin edge in the distal part; the immovable finger is also provided with two broad truncated teeth on the cutting edge; a small flange, the end of which is obtuse, is produced forwards at the distal one-third point of the immovable finger on the anterior border; the palm is greatly swollen and broad, being slightly less than one and a half times as long as broad; the merus is somewhat longer than the ischium, and is armed with a stout spine at the distal margin of the posterior bordcr.

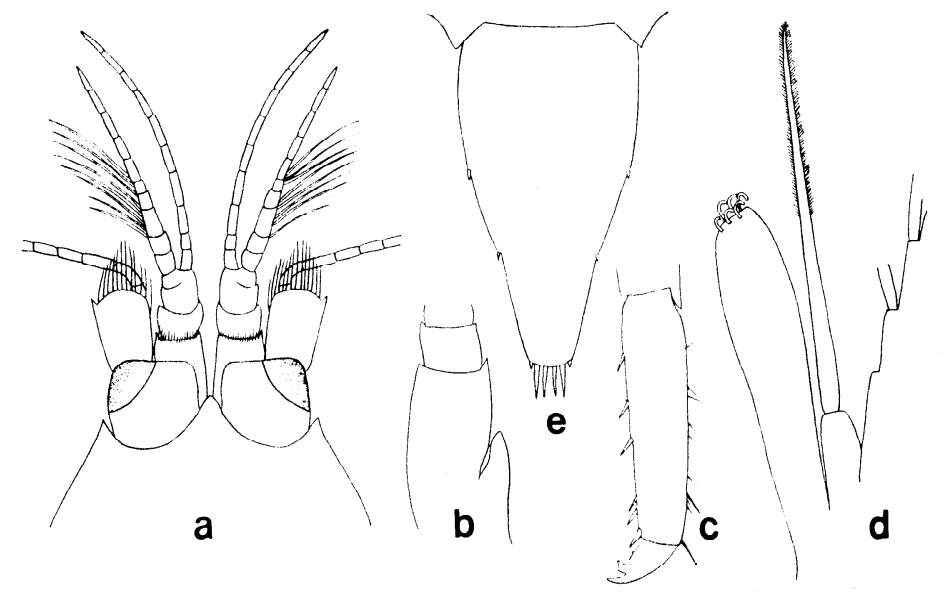

Fig. 5. Onycocaris quadratophthalma (Balss), a, anterior part of body in doseal view; $b$, antennular peduncle; $c$, distal part of third pereiopod; d, appendix masculina ; e, telson.

The last three pereiopods are robust. The dactylus of the third pereiopod is distinctly biunguiculated into two teeth, the distal of which is pointed, while the proximal is short and somewhat broad with the fine serration; the propodus is about as long as the merus, and is flanked with a row of some spinules at its posterior border; the fourth and fifth pereiopods are equal in shape to the third, but are more slender (Fig. $5, \mathrm{c})$.

The abdomen is smooth, being slender in both the male and young females, while the ovigerous female is swollen; the ventral margins of the first three segments are round but those of the fourth to sixth are dull with the triangular shape. The appendix masculina is much shorter than the appendix interna and bears a strong seta at the top (Fig. 5, d).

The telson is rather broad, tapering to the end; it bears two pairs of the minute dorsal spines just at the lateral margins, the proximal of which is situated slightly before the middle of the telson, and the other 
is before the midway between the proximal pair and the end of the telson; among the three pairs of terminal spines the outer is extremely small and the rest are much longer and subequal (Fig. 5, e).

Measurements. In regard to the three male specimens the carapace measures $2.8 \mathrm{~mm}$ in maximum, and in the five females it attains $3.8 \mathrm{~mm}$. The specimens collected from Shiroiwazaki are all young, measuring about $5 \mathrm{~mm}$ in body length.

Distribution. This species may be new to the fauna of Japan. The records in literature are: Cape Jaubert, N. W. Australia (Balss, 1921), Wake Island (Edmondson, 1925), Pearl and Hermes Reef, Hawaii (Edmondson, 1925), Hawaii (Edmondson, 1946).

Remarks. The present specimens generally agree with Balss' (1921) original description based on one ovigerous female, from which, however, they are somewhat different in the following points. The rostrum forms a small protuberance which is shorter than the anterolateral process of the carapace in the original description instead of having the strong projection reaching slightly beyond the anterolateral process in the present specimens. Although he describes that the stylocerite is lacking in his specimen, a broad one should present in the present specimens that is closely near the outer margin of the first segment of the antennular peduncle. Presumably, he must have overlooked the stylocerite because of its being concealed by the broad eye. The dactylus of the first periopod in his original account is much shorter and the carpus is much slender than those respective parts in the present specimens. The posterior margins of the carpus, merus and ischium, and also the anterior margin of the carpus are seen as round in his figure, while those of the present spccimens are ending in a distinct angle.

This species, as is known from its trivial name, is recognized by having the quadrate form of the eyestalk, so that the cornea is situated at the anterolateral side of the eyestalk.

Edmondson (1946) reports that this species is concealed in the tubular sponges which are attached to under surfaces in the shallow waters. The present specimens, including the ones from Shiroiwazaki which were collected from in the sponge that had been cast by the waves upon the shore, were all commensal with the sponge, Callyspongia elegans (Thiele) which is common in the coastal reef from Chiba Prefecture, Japan southwards to the tropical waters.

Periclimenaeus gorgonidarum (Balss, 1913)

(Figs. 6 and 7 , a-e)

Periclimenes gorgonidarum Balss, 1913, p. 236 (original description); 
Balss, 1914, p. 51, figs. 31, 32 (description); Borradaile, 1917, p. 376 (list) ; Kemp, 1922, p. 138 (discussion); Kubo, 1940, p. 38, figs. 6-7 (description).

Periclimenaeus gorgonidarum; Holthuis, 1952, p. 129 (discussion).

Material examined. Tsuyazaki, Fukuoka Prefecture, Kyushu, gill net, 1 ๙. ZLKU No. 3427, June 13, 1966, T. Fujino leg.

Tsuyazaki, Fukuoka Prefecture, Kyushu, 1 ovig. ㅇ, ZLKU No. 3428, July 14, 1966, K. Gushima leg.

Tsuyazaki, Fukuoka Prefecture, Kyushu, 1 ð, 1 ovig. 우, ZLKU No. 3429, July 15, 1966, K. Gushima leg.

Description. The body is smooth and rather compressed (Fig. 6).

The rostrum is produced slightly upwards, decreasing its breadth gradually towards the tip which ends in a sharp tooth; it is half the length of the carapace, reaching about to the end of the second segment of the antennular peduncle; on the upper border there are seven to nine scrrated teeth which are subequal in size; among them the first is situated on the carapace; on the lower border one or two teeth are placed near the tip of the rostrum.

The carapace is smooth and slightly swollen at the cardiac region; the length of the carapace is a little less than its breadth, having a small supraorbital spine situated behind the eye and a pointed antennal spine placed slightly above the base of the antennal peduncle; there is a very obscure cervical groove on the carapacc.

The first segment of the antennular peduncle is broad, and the outer margin is convex; the triangular process of the anterolateral margin of the first segment ends in a pointed spine, reaching to the distal end of the second segment; the stylocerite is blunt and foliaceous, the base of which is somewhat narrow, and does not extend to the half point of the first segment of the antennular peduncle; the second segment is short, being less than the third in length; the second and third segments together are half the length of the first; the outer flagellum is bifurcated into two rami at the fifth fused joints, the shorter of which consists of three joints (Fig. 7, a).

The eye is normal in form, being rather slender anteroposteriorly; the cornea is well pigmented.

The antennal scale is short and broad, measuring twice as long as broad; it reaches to the end of the third segment of the antennular peduncle; the outer margin of the scale is straight or slightly concave, ending in a strong tooth just extending to the round end of the lamella (Fig. 7, b).

The third maxilliped is pediform; the ultimate segment is as long as the penultimate, and the antepenultimate is twice the length of both the distal two segments. 
The first pereiopod is considerably slender; both of the cutting edges lack any tooth, forming the entire margin; the chela with the short movable finger, is straightly elongated; the carpus is as long as the merus, becoming stouter distally.

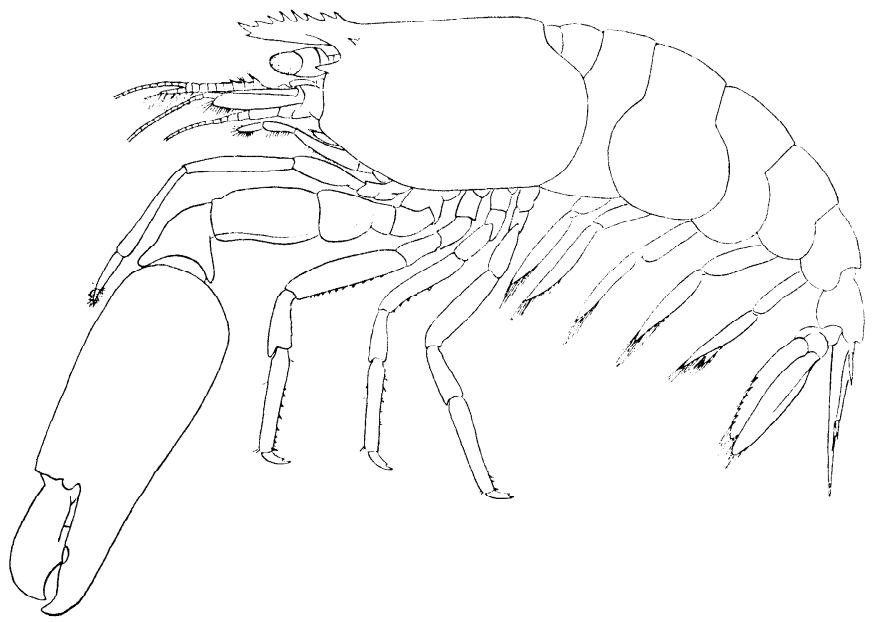

Fig. 6. Periclimenaeus gorgonidarum (Balss), $\times 4.8$.

Both the second pereiopods are unequal in size, and they are heavy and swollen; the tips of the fingers are inturned, crossing each other when closed; the cutting edge of the movable finger bears a large bluntly truncated tooth, which fits into the socket of the immovable one; the surface of the cutting edge of the movable finger, is slightly hollowed; the immovable finger extends beyond the tip of the movable; the anterodorsal margin of the movable finger is curved somewhat deep$1 \mathrm{y}$, while that of the immovable is not so much curved; a large, blunt tooth forming a inner posterior margin of the socket, is situated on the cutting edge of the immovable finger; there are many short hairs distally scattered on the chela distally; the palm is more than twice as long as broad and also more than one and a half times the length of the movable finger.

The third and fourth pereiopods are provided with a large number of spinules on each of the posterior border of the propodus, carpus and merus, but the fifth is not armed with these spinules except for the distal three pairs of the spinules developed on the propodus; each dactylus of the third to fifth pereiopods is biunguiculated and considerably bends ventrally; the posterior margin of the dactylus has many minute denticles; the third pereiopod is longer and stouter than the other two 
ones, especially in the merus (Fig. $7, \mathrm{c}, \mathrm{d}$ ).

The abdomen is smooth; the endopod of the second pleopod is provided with a shorter appendix masculina having some stout setae at the tip and a longer appendix interna without any setae.
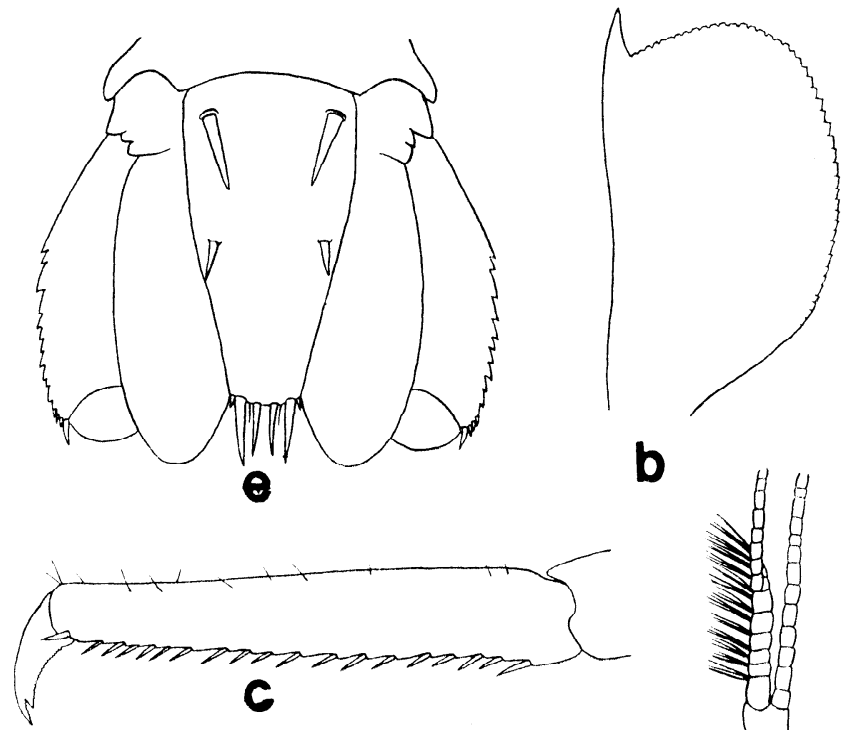

b

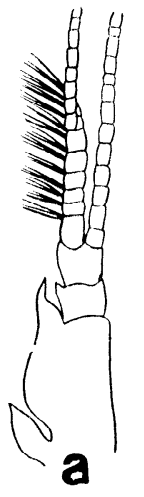

Fig. 7. Periclimenaeus gorgonidarum (Balss), a, antennular peduncle ; $b$, antennal scale ; c, distal part of third pereiopod; d, distal part of fifth pereiopod; e, tail fan.

The telson is a little less than twice as long as broad at the base, being narrow towards the end which is less than half times as broad as the broadest portion; there are two pairs of spines on the dorsal side of the telson, the proximal of which is longer than the distal and situated near the base of the telson, while the distal is placed at about the middle of the telson; there are three pairs of the terminal spines, the outer is very short and the intermediate is long and stout. The uropod is considerably longer than the telson; the outer margin of the exopod of the uropod is serrated or spinulous and armed with three to six movable spinules distally (Fig. 7, e). 
Colour. The body in living is semi-transparent and tinged whitish. On the rostrum, dorsal side of the carapace and pleura there are a great many red or bitter orange chromatophores scattered not uniformly. The third maxilliped and second pereiopod are also provided with numerous, red, minute spots, chiefly on the chela of the second pereiopod.

\begin{tabular}{lcccc}
\multicolumn{2}{c}{ Measurements (mm). } \\
ZLKU Cat. No. & $3427($ ふ) & 3428 (ovig. 우) & 3429 (ð) & 3430 (ovig. 우) \\
Length of carapace & 4.4 & 6.0 & 3.7 & 5.0 \\
Breadth of carapace & 4.1 & 6.0 & 3.4 & 5.0 \\
Length of rostrum & 2.0 & 2.6 & 1.9 & 2.0 \\
Length of telson & 2.9 & 4.0 & 2.5 & 3.5 \\
Length of scaphocerite & 1.9 & 2.0 & 1.9 & 1.9
\end{tabular}

Distribution. The species is recorded only from Japan. The records in literature are: Sagami Bay near Misaki, Kanagawa Prefecture (Balss, 1913, 1914); Hurue, Kitaura, Miyazaki Prefecture, Kyushu (Kubo, 1940).

Remarks. The present specimens agree well with Balss' (1913) original description. They also agree with the description given by Kubo (1940), excepting the fact that each dactylus of the third to fourth pereiopods is not serrated.

Balss (1914) records one female specimen as being associated with a Gorgonaria, while the present specimens were all commensal with the same kind of the sponge, Callyspongia confoederata (Ridley) which was collected in the depth of six to eight meters.

\section{References}

Balss, H., 1913. Diagnosen neuer ostasiatischer Macruren. Zool. Anz., vol. 42, pp. $234-239$

, 1914. Ostasiatische Decapoden II. Die Natantia und Reptantia. In: Doflein, F., Beiträge zur Naturgeshichte Ostasiens. Abh. Bayer. Akad. Wiss., suppl. vol. 2, pt. 10., pp. 1-101, textfigs. 1-51, p1. 1.

, 1921. Stomatopoda, Macrura, Paguridea und Galatheidea. Results of Dr. E. Mjöbergs Swedish Scientific Expeditions to Australia 1910-1913. XXIX. K. Svenska Vetensk. Akad. Handl., vol. 61, pt. 10, pp. 1-24, figs. 1-12.

Borradaile, L. A., 1917. On the Pontoniinae. The Percy Sladen Trust Expedition to the Indian Ocean in 1905, under the leadership of Mr. J. Stanley Gardiner. Trans. Linn. Soc. Lond. Zool., ser., 2, vol. 17, pp. 323-396, pls. 52-57.

Edmondson, C. H., 1925. Crustacea. Marine zoology of tropical Central Pacific. (Tanager Exped. Publ. 1). Bull. Bishop Mus. Honolulu, n. 27, pp. 3 62, pls. 14.

, 1946. Reef and shore fauna of Hawaii. Spec. Publ. Bishop Mus. Honolulu, vol. 22, pp. i-iii, 1-381, figs. 1-223.

Gordon, I., 1935. On new or imperfectly known species of Crustacea Macrura. J.

Linn. Soc. Lond., Zool., vol. 39, pp. 307-351, figs. 1-27. 
Holthuis, L. B., 1952. The Decapoda of the Siboga Expedition. Part XI. The Palaemonidae collected by the Siboga and Snellius Expeditions with remarks on other species. II. Subfamily Pontoniinae. Siboga Exped. 39a10, pp. 1-253, figs. 1-110. , 1955. The recent genera of the Cariden and Stenopodidean shrimps with keys for their determination. Zool. Verhand. no. 26, pp. 1-157, figs. 1-104.

Kemp, S., 1922. Pontoniinae. Notes on Crustacea Decapoda in the Indian Museum. XV. Rec. Indian Mus., vol. 24, pp. 113-288, figs. 1-105, pls. 3-9. , 1925. On various Caridea. Notes on Crustacea Decapoda in the Indian Museum. XVII. Rec. Indian Mus., vol. 27, pp. 249-343. figs. 1-24.

Kubo, I., 1940. Pontoniinae. Studies on Japanese palemonoid shrimps. II. J. Imp. Fish. Inst. Tokyo, vol. 34, pp. 31-75, figs. 1-36.

Nobili, G., 1906. Faune carcinologique de la Mer Rouge. Décapodes et Stomatopodes. Ann. Sci. nat. Zool., ser. 9, vol. 4, pp. 1-347, textfigs. 1-21, pls. 1-11.

, 1906a. Diagnoses préliminaires de Crustacés, Décapodes et Isopodes nouveaux recueillis par M. le Dr. G. Seurat aux iles Touamotou. Bull. Mus. Hist. nat. Paris, vol. 12, pp. 256-270.

Paulson, O., 1961. Studies on Crustacea of the Red Sea with notes regarding other seas. Pt. I. Podophalmata and Edriophthalmata (Cumacea). pp. i-vii, 1-164, pls. 1-21, Jerusalem. "English translation of the original Russian publication for 1875." 


\section{Explanation of Plate 3}

Anchistioides compressus Paulson living commensally with a sponge, Haliclona oculata (Linnaeus). 


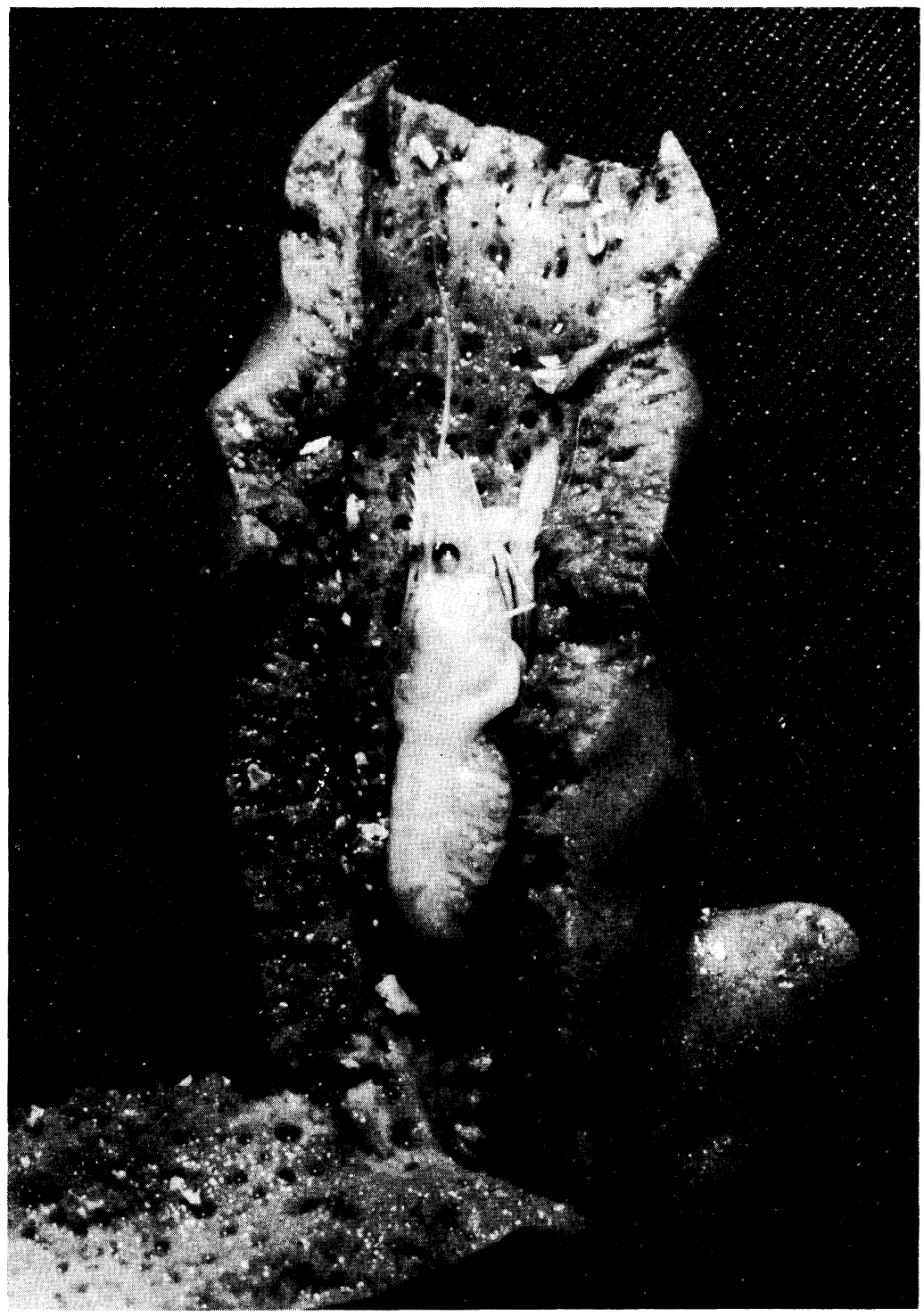

Four species of Pontoniinae found in Porifera 